\title{
The Formation of Economic Perceptions in Post-Communist Countries of East Central Europe
}

\author{
Yuliya V. Tverdova
}

Published online: 18 March 2011

(C) The Author(s) 2011. This article is published with open access at Springerlink.com

\begin{abstract}
In the early transition phase in post-communist Europe, citizens' perceptions of the national economy appeared more favorable than objective economic indicators would suggest. With triple and quadruple digit annual inflation rates and a severe economic contraction, there was a substantial portion of the population in these countries who still thought that the national economy had been and would be improving. Thus, sociotropic economic perceptions in the wake of the democratic transformation appeared to be disconnected from the real economic situation. The purpose of this paper is threefold. First, it explores the link between objective economic indicators and public evaluations of the economy. Second, it investigates the microfoundations of economic perceptions. And finally, it tests a well-established proposition that political sophisticates are more accurate in their perceptions than their less informed counterparts. The findings of the study can be generalized to any political and economic system undergoing transition.
\end{abstract}

Keywords Economic perceptions - Post-communist - Transition · Economic voting $\cdot$ Information shortcuts $\cdot$ Accountability

One of the grounding postulates of democratic theory is the principle of accountability. The theoretical operation of the accountability mechanism is quite simple: elected officials bear responsibility for their performance and receive reward or punishment from their constituency accordingly in the form of re-election or denial of a future political mandate. In reference to economic accountability, the mechanism presumes government responsibility for the state of the national economy, also known as economic voting (Lewis-Beck 1988; Page and Shapiro

Y. V. Tverdova ( $\square$ )

University of California-Irvine, 3151 Social Science Plaza, Irvine, CA 92697, USA

e-mail: tverdova@uci.edu 
1992; Alvarez and Nagler 1998; Nannestad et al. 2003). As noted by Nannestad and Paldam (2000), the link between the state of the national economy, or "objective" economy, and the act of voting proceeds through several phases. First, objective economic information has to be perceived by potential voters. The resulting perceptions ideally reflect economic reality. Then, public perceptions must be connected to evaluations of government economic competence and, finally, lead to a voting decision.

For a long time, economic voting models treated economic perceptions as exogenous and based on reality. Without the latter, the normatively appealing mechanism of electoral accountability breaks down. Without the former, scholars face the unpleasant endogeneity dilemma. Empirical studies, however, have been consistently pointing to the fact that democratic publics are less sophisticated than expected by democratic theorists, and their economic assessments often deviate from macro-economic realities (Borre 1997; Evans 1999). Most importantly, a number of recent works - a revisionist trend in the economic voting literaturehave demonstrated that these deviations are systematic, rather than random, in nature (Anderson 2007; Wlezien et al. 1997; Anderson et al. 2004; Johnston et al. 2005; Enns and Anderson 2009; Evans and Andersen 2006; Evans 1999).

Along with personal economic experiences, the revisionist argument places a major emphasis on people's political predispositions as a source of economic biases. A part of the argument deals with the endogenous effect of past vote choice, which is also known in the literature as the "winner-loser effect" (Anderson et al. 2007). In this story, having voted for the winner of the election makes one more likely to have a positive outlook on government's economic performance, whereas having voted for the loser increases the probability of negative perceptions. The reason behind this claim is an intrinsic desire in humans to maintain cognitive consistency (Festinger 1957; Mattila 1998; Vláchová 2001).

A larger theoretical framework includes any form of political attitudes likely to influence one's general evaluations of government performance. Partisanship and political ideology are certainly central to this line of argument (Enns and Anderson 2009; Evans and Andersen 2006; Evans 1999). Instead of relying on objective economic indicators, voters view the economy through the prism of partisan lens and assign credit and blame accordingly. Also, since partisanship drives both economic evaluations and voter choice, the relationship between the latter two may be significantly overstated (Wlezien et al. 1997; Johnston et al. 2005; Evans and Andersen 2006; Anderson et al. 2004; Enns et al. 2008; Conover et al. 1987). The most recent series of studies investigates how electoral expectations affect public economic forecasts and actual consumption behavior (Ladner and Wlezien 2007; Enns and Anderson 2009; Gerber and Huber 2009, 2010). When partisans anticipate their party to win the next election, they tend to develop more optimistic perceptions of the future economy. Moreover, partisans adjust their economic decisions based on whether their preferred party holds power, which further establishes a powerful effect that political variables exert over economic perceptions and behavior.

The causal relationship between economic and political variables has been a hot topic among the scholars of economic voting. While there is a fairly broad agreement that politics affects economic perceptions, the causal flow is likely to run 
in both directions. The most recent work by Lewis-Beck et al. (2008) struck back at revisionists with new sophisticated evidence about the importance of economic assessments for political decisions. Using data from three Western democraciesthe US, Canada and the UK-the authors demonstrate a strong direct effect of economic perceptions on political behavior. Yet they also confirm that economic evaluations are endogenous to political variables.

In times of economic crises and transition, the relationship between economic reality and perceptions may be even more distorted. On one hand, economic turmoil introduces distress into daily lives of individuals, which may lead to heavy reliance on personal economic experiences for judging the national economy (Mutz 1992). On the other hand, economic transitions (and crises) often bear a high degree of uncertainty and volatility, thus making it harder for citizens to assess the situation accurately. This study explores the level of distortion between the objective economy and public economic perceptions at the wake of post-communist transition in East Central Europe. It aims at identifying the possible sources of economic biases as well as the mediating forces behind them.

With the collapse of the command economy, the general economic conditions in these countries hit rock bottom, and most people found themselves in deep poverty. While citizens fought for everyday economic survival, the elites fought for political survival by making promises of a prosperous economic future (e.g. Ahl 1999). Yet a closer look at public economic perceptions alongside indicators of the macro economy during the early transition reveals some noticeable discrepancies between a poor national economic state and unusually high sociotropic evaluations (comparable to public economic assessments in developed democracies for the corresponding time period), especially regarding the near-term economic future.

This leads to my first research question of whether the link between objective economic indicators and popular perceptions of the economy break down during a transition that includes economic and political restructuring. It may be that the transition in regime form shapes economic perceptions and expectations independent of reality. Similar to how partisanship affects economic perceptions in stable democracies, adherents of the new regime are buoyed by a sense of optimism of the changes ahead, while adherents of the old regime are overly pessimistic. The economic turbulence of the transition may also blur perceptions of the objective economic conditions. The question, then, is: Did the "objective" state of the national economy drive sociotropic economic perceptions in the emerging democracies of East Central Europe at the beginning of the post-communist transition?

If, however, as I suspect, economic perceptions of post-communist citizens were inaccurate, what would be the major possible sources of these biases? Most scholars of public opinion in general and economic perceptions in particular draw heavily on decision-making and opinion formation theories developed by social psychologists (Kahneman et al. 1982; Plous 1993; Gilovich et al. 2002). They assert that individuals rely on heuristic mechanisms to form opinions rather than engage in knowledge-based deliberation. It is generally believed that relying on heuristics and wishful thinking is inversely related to the level of knowledge on a certain subject. 
Yet, some argued that even most knowledgeable individuals often resort to heuristics while making decisions in circumstances of uncertainty.

Thus, the second research question calls for the identification of important heuristics (also known as motives or shortcuts) that should help us understand in a systematic way how economic judgments were formed in East Central Europe. Building upon previous economic voting studies, I posit that citizens used the most accessible and salient information available to them at the time of the survey, such as their personal economic well-being and political affiliations, and especially attitudes toward the new regime. Moreover, people's attitudes toward the new (and old) regime in general may have attenuated the way they viewed the national economy. Those who were enthused about the change could have been more motivated to form positive economic evaluations, both past and future. As a result, in supporters, the link between the objective and subjective economies may have been more distorted.

Finally, economic sophistication may operate as a mediating mechanism between information shortcuts and national economic evaluations. Those with more knowledge of the economy should be less compelled to rely on heuristics. My third hypothesis, therefore, is interactive in nature and deals with the proposition that economic sophisticates should be more accurate in their economic evaluations than their less informed counterparts.

\section{Economic Perceptions in Central and Eastern Europe: Knowledge-based or Wishing Thinking?}

The scope of the research from over almost two decades of economic voting studies in the post-communist nations has reached that of Western democracies (see Tucker 2002 for a comprehensive review). Yet studies exploring the formation of economic evaluations per se are scarce. To date, a study by Anderson and O'Connor (2000) is the only systematic analysis of the formation of economic perceptions in that region. Specifically, the authors examined the formation of economic perceptions in East Germany under conditions of radical system change. Their findings revealed a poor match between objective economic conditions and public perceptions about the national economy during the initial stage of the transition. However, as time passed, sociotropic perceptions started tracking the objective economy more closely.

Anderson and O'Connor's study suggests that economic evaluations are both knowledge based and affective. East German citizens were inaccurate in the wake of the transition because they lacked knowledge about the transition, but also because they experienced euphoria after the communist system collapsed. The authors posited that people in new democracies had to "learn" before they began to form more accurate perceptions of the economy, i.e. congruent with objective economic indicators. Moreover, once the early stage of transition-the "honeymoon"passed, people became more critical of the conditions in the country and started to hold the current government, not the past regime as during the "honeymoon" period, accountable for the state of the economy. 
Given the specific research question the authors had in mind, however, they did not explore the mechanism of individual-level opinion formation in the early transition, and were thus unable to provide insight into whether economic perceptions were systematically driven by factors other than the objective economy. This is what this study aims to do. One of the most plausible explanations offered by social psychologists and political scientists is that people tend to simplify the decision-making process and heavily rely on heuristics, motivated reasoning, as well as wishful thinking, especially when their knowledge on the subject is sparse (Kahneman et al. 1982; Zaller 1992; Lau and Redlawsk 2001; Kuklinski et al. 2001; Neuwirth et al. 2002).

Dolan and Holbrook (2001) have aptly described the debate about the sources of public opinion as the role of affect versus cognition in the formation of perceptions. In the absence of cognitive resources, but arguably even when such resources are present (Kahneman et al. 1982; Babad 1995), individuals tend to resort to emotion, affect, and predispositions to help them form judgments (Lavine et al. 2005). As a general rule, people tend to fit their perceptions of reality into their preexisting picture of the world or a set of longstanding preferences (Dolan and Holbrook 2001), thus achieving cognitive consistency (Festinger 1957). In the end, people's aspirations for cognitive consistency lead them to be highly selective in what information they receive or accept according to their predispositions (Dolan and Holbrook 2001; Lavine et al. 2005). Put differently, individuals are likely to reach conclusions that they want to reach (Kunda 1990).

Wishful thinking is a related concept, which mostly refers to perceptions about the future. In a series of experiments, social psychologists revealed that wishful thinking is widely present among sports fans and even sports bettors who ignore the odds of their favorite team to win (Babad 1987; Babad and Katz 1991). In electoral studies, the effect of wishful thinking has been explored in the U.S., Sweden, Israel and other democratic states (Granberg and Brent 1983; Babad et al. 1992; Babad and Yacobos 1993; Babad 1995). All of the authors registered the operation of a wishful thinking mechanism among voters in predicting election outcomes. However, the investigation of the role of knowledge in attenuating the effect of wishful thinking has yielded mixed results. Whereas Granberg and Brent (1983) found that in US presidential elections wishful thinking was strongest among poorly informed citizens, Babad (1995) was unable to support this finding in his study of the 1992 Israeli election.

If people's perceptions of the economy at the early transition stage in East Central Europe were disconnected from the objective economic reality, what were they based on? Zaller (1992) asserts that it would be the most accessible information-information 'off the top of your head' - that would be retrieved from the memory to form a judgment. According to some, personal experiences and interpersonal communication are important sources of sociotropic economic perceptions (Mutz 1992; Conover et al. 1986). Mutz (1992) further insists that personal experience is "superior" to all other sources of sociotropic economic perceptions. The mechanism here is very simple: personal experience (whether a person's own experience or experience of somebody from his or her social environment) is difficult to deny and can be used as a powerful base for critical 
evaluation of economic information coming from other sources. Because personal experiences and interpersonal communication patterns vary by individual, perceptions derived from these experiences are also likely to be individually determined, and therefore could be systematically biased (Duch et al. 2000).

Another major source of perceptual economic biases derives from people's political predispositions. As a result of numerous revisions of the traditional economic voting modes, there is a general agreement now about the importance of political variables for economic perceptions. Most individuals form political values and even party attachments early in their lives and tend to judge future information about the world based on their political ideology. Recent history of the postcommunist transformations revealed the duality of the transition; in other words, political reforms were closely intertwined with economic reforms (e.g. Colton 2000; Duch 1993; Przeworski 1991; Tóka 1995) ${ }^{1}$. Consistent with this, I posit that political and economic evaluations were closely connected in people's minds. Those who expressed satisfaction with political performance may have also expressed satisfaction with economic performance even if in actuality national economic indicators signaled a severe crisis.

In addition, mass media and new political elites were very active in disseminating information about democratic ideas. Thus, we can assume the existence of a certain level of support for democracy and the market even at the early stages of democratization. Besides, the notion of democracy was likely to represent a political system different or even opposite to the past Soviet system. ${ }^{2}$ People who expressed support for a certain political order (the new or the old one) may also be expected to be more tolerant of the hardships associated with establishing and maintaining this regime, including economic shortcomings (Gibson 1996a, b).

Besides personal experiences and political predispositions, citizens in East Central Europe, as citizens in any other country, also differed in their access to political and economic information as well as their ability to process it. It is

\footnotetext{
${ }^{1}$ A connection between the polity and the economy is obvious to the extent that political decisions and government politics affect economic behavior and business performance. Concurrently, economic outcomes prompt politicians either to modify the current economic policies, develop new ones, or to continue with the old policies. In Western democracies, public evaluations of the national economy have been found to be affected by assessments of government performance, but the magnitude of this relationship is modest. The effect of political evaluations on mass opinion of the national economic state in the post-communist nations is expected to be of higher substantive value, because democratic reforms were interwoven into economic reforms.

${ }^{2}$ It is noteworthy that Russia displays substantially lower public support for the ideal of democracy than all the other post-communist countries. For example, according to Political Indicators compiled by Fessel-GfK (Austria), only 32 percent of respondents in Russia expressed full support for democracy in 2001 compared to at least 45 percent in the next lowest case (Bulgaria). The highest support for democracy that Russia ever displayed was in 1994 (50 percent), and in all other years before and after 1994 it never rose higher than 40 percent, which is substantially lower than in other post-communist countries. This may be partially determined by the exclusive role that the Russian Federation played in the Union of the Soviet Socialist Republics, as well as on the whole territory of the communist space. Consequently, after losing the hegemonic power over the rest of the communist states, some Russians may have felt nostalgic about the Soviet Union; hence, they expressed lower support for a democratic system.
} 
common to think that political sophistication gives people more intellectual and material resources to form accurate evaluations of the reality and act rationally. Empirical studies of the mediating effect of political sophistication on the formation of public opinion, however, have yielded mixed results (Zaller 1992; Babad 1995; Kumlin 2001; Baum 2002). Karp et al. (2003), for instance, found that more and less politically aware persons base their evaluations of the EU on different factors. In particular, more sophisticated individuals incorporate assessments of EU institutions, while their less informed counterparts do not. In contrast, Goren (2004) claimed that people at various levels of sophistication had more or less uniform core values and beliefs and relied equally on them when forming political judgments.

Many social scientists also assert that a higher level of education is likely to enhance political knowledge (Berggren 2001). This assumption, however, may not have held in the post-communist nations during the initial stage of the transformation for at least two reasons. Firstly, at the beginning of the transition reforms, the highly educated were unlikely to have better knowledge of democracy and the market than the less educated, because these topics were not covered during the course of formal schooling during socialism. Information on the Western democratic system was also unavailable from other sources except underground or smuggled publications. Thus, the more educated were not privileged, save a few, in having a better understanding on how democracy worked, although they may have had higher learning capabilities.

Secondly, judging by the literature on income structure in post-communist nations, positive returns to education were negligible (Jensen 2003). Put differently, persons with higher formal education were not likely to have a better salary. Consequently, it would not be fair to say that the more educated could enjoy better opportunities, financially speaking, to access information. Having said that, however, it is unreasonable to deny that education contributes to the development of better logical skills, and hence advanced information processing skills, in general.

In contrast, interpersonal communication is a cheap way to acquire economic and political information. Essentially, all it takes is a willingness to engage in a political conversation, and sometimes even less than that-simply listening to what other people say. Thus, political discussion may become a primary source of economic and political information leading to the formation of public opinion. Based on past research, many individuals do not form political judgments from media reports before they discuss them with someone they trust on political matters. Conveniently, such a trustworthy person is normally not hard to find, since individuals, on average, tend to think that people around them are more politically sophisticated than they are.

Again, in the context of newly emerging democracies, when information was scattered and confusing, interpersonal discussion may have become the most influential source of knowledge on the economy and politics. Political discussion is likely to lead to biased economic judgments, since one's discussion networks tend to be homogeneous. In post-communist nations, similar to other countries in this regard, discussion networks were traditionally comprised of relatives, friends, and colleagues, thus providing anecdotal evidence in support of the homogeneity assumption. Moreover, the tone of political discourse was person-centered with a 
prevailing pessimistic connotation (Shevchenko 2001; Ries 1997). In other words, people often complained in private conversations, thus possibly contributing to the creation of a negative image of the general situation in the country.

What follows from the above may be summarized in four general hypotheses tested in the present study.

Hypothesis 1 There was no substantively significant relationship between objective economic indicators and public perceptions of the national economy at the early phase of the post-communist transition, even if the relationship was statistically significant.

Hypothesis 2a Perceptions of the national economic situation at the early stage of the post-communist transition were driven by personal economic experiences, attitudes toward the new and old regime, as well as evaluations of the performance of the political system.

Hypothesis 2b Perceptions of the national economy at the early state of the postcommunist transition were attenuated by individuals' attitudes to the new and old political regimes.

Hypothesis 3 Perceptions of the national economy at the early stage of the postcommunist transition were attenuated by individuals' levels of political sophistication (measured here as education and political discussion).

\section{Preliminary Evidence}

Let me begin by painting a broader picture of the economic reality and economic perceptions in the post-communist region in the early $1990 \mathrm{~s}$. Table 1 shows objective economic data for 17 new democracies in the region for 1991-1992 collected by the European Bank for Reconstruction and Development and aggregate retrospective and prospective perceptions of the national economy for 1992 taken from the respective Central and Eastern Eurobarometer study. ${ }^{3}$ In addition, Table 1 depicts the proportions of the population in those countries who thought that the national economic situation had gotten better or much better over the previous year.

A first look at the inflation, unemployment, and GDP growth rates in the 17 nations for 1991-1992 would probably make us think that there should be no one in those countries who would think that the national economic situation had improved. How can a triple-digit inflation rate be considered an improvement? However, as can be clearly seen from Table 1, a significant portion of the population in postcommunist countries in 1992 thought that the national economy had gotten better in

\footnotetext{
3 The macroeconomic data come from a 1999 European Bank for Reconstruction and Development Report. Because these data may have been reevaluated and recalculated retrospectively, some concerns exist about how close these data are compared to the ones that post-communist citizens received through the media at the time of the survey. To address this concern, I searched for the macroeconomic data released around the time of the survey. The journal Economics of Transition used to publish quarterly reports of the economic developments in the region and their statistics were largely of the same magnitude as the EBRD report.
} 
Table 1 Favorable sociotropic perceptions and national economic indicators by country

\begin{tabular}{|c|c|c|c|c|c|c|c|c|}
\hline \multirow[t]{2}{*}{ Country } & \multirow{2}{*}{$\begin{array}{l}\% \text { of respondents } \\
\text { with favorable } \\
\text { retrospective } \\
\text { perceptions }\end{array}$} & \multirow{2}{*}{$\begin{array}{l}\% \text { of respondents } \\
\text { with favorable } \\
\text { prospective } \\
\text { perceptions }\end{array}$} & \multicolumn{2}{|c|}{ Inflation } & \multicolumn{2}{|c|}{ Unemployment } & \multicolumn{2}{|l|}{ Growth } \\
\hline & & & 1991 & 1992 & 1991 & 1992 & 1991 & 1992 \\
\hline Albania & 46.53 & 74.72 & 104.0 & 236.6 & 9.5 & 27.0 & -27.7 & -7.2 \\
\hline Armenia & 3.71 & 16.81 & 25.0 & 1341.0 & & 3.5 & -10.8 & -52.6 \\
\hline Belarus & 9.42 & 20.24 & 93.0 & 1159.0 & .0 & .5 & -1.2 & -9.6 \\
\hline Bulgaria & 30.55 & 50.61 & 339.0 & 79.4 & 10.5 & 13.2 & -11.7 & -7.3 \\
\hline Czech & 23.81 & 37.66 & 52.0 & 12.7 & 4.1 & 2.6 & -14.2 & -3.3 \\
\hline Slovakia & 13.50 & 24.06 & 58.0 & 9.1 & 11.8 & 11.4 & -14.6 & -6.5 \\
\hline Georgia & 12.40 & 42.46 & 131.0 & 1177.0 & & .9 & -13.8 & -44.8 \\
\hline Hungary & 9.21 & 18.43 & 32.0 & 21.6 & 7.8 & 13.2 & -11.9 & -3.1 \\
\hline Latvia & 7.25 & 25.03 & 262.0 & 959.0 & & 2.3 & -8.3 & -34.9 \\
\hline Lithuania & 4.06 & 28.92 & 345.0 & 1161.1 & .3 & 1.3 & -13.4 & -37.7 \\
\hline Macedonia & 7.72 & 39.82 & 230.0 & 1925.2 & 19.2 & 19.8 & -12.1 & -21.1 \\
\hline Moldova & 14.83 & 22.15 & 151.0 & 2198.0 & & .1 & -17.5 & -29.1 \\
\hline Poland & 20.68 & 28.52 & 60.0 & 44.3 & 12.2 & 14.3 & -7.0 & 2.6 \\
\hline Romania & 26.39 & 39.56 & 223.0 & 199.2 & & 8.2 & -12.9 & -8.7 \\
\hline Russia & 13.95 & 28.06 & 144.0 & 2508.8 & .0 & 4.8 & -13.0 & -14.5 \\
\hline Slovenia & 35.75 & 55.66 & 247.0 & 92.9 & 8.2 & 11.6 & -8.1 & -5.5 \\
\hline Ukraine & 10.61 & 29.72 & 161.1 & 2730.0 & .0 & .3 & -9.0 & -13.7 \\
\hline
\end{tabular}

spite of the dreadful economic statistics for that year. In one-third of the countries, over $20 \%$ of the citizens evaluated the national economy as improving. In another third of the countries more than $10 \%$ thought that the economy had performed better than 12 months before. In Albania and Slovenia, the proportion of population approving of past economic performance exceeded one-third.

Looking ahead, post-communist citizens tended to be even more optimistic. In all 17 countries in the 1992 survey, future economic forecasts for the following year were much more favorable than evaluations of past performance, which suggests that wishful thinking may very well have taken place of pure rationality. Thus, almost three quarters of Albanians felt positively about the economic future of their country. In Slovenia and Bulgaria, economic optimists constituted a majority; yet over 80 percent of Hungarians and Armenians did not envision any improvement in their national economies for the year ahead. In the rest of the countries, the figure for those who believed in the economy getting better ranges from about 20 to 40 percent.

Although a more thorough analysis is necessary to estimate the relationship between objective and subjective economies, the first look suggests that there is some degree of incongruence between the reality and public perceptions. This lack of congruence would be consistent with Anderson and O'Connor's (2000) study of national economic evaluations in East Germany. Recall that the authors explained the disconnection between public opinion and the economic reality by a lack of 
familiarity about the new economic system and also by an overall euphoria about the transition (see also Tóka 1995).

It should also come as no surprise that economic expectations seemed even more detached from the current state of the economy than past economic evaluations. While the economic past is already determined, the economic future is uncertain and may be a projection of people's high hopes for a quick recovery of the national economy. As argued by Stokes and others (e.g. Stokes 1996, 2001; Przeworski 1996), in new democracies, people may believe that things have to become worse before they get better; therefore, the drastic economic situation in East Central Europe may have been perceived by the citizens as a sign of progress in the transition. In summary, past studies of public opinion and electoral behavior in postcommunist Europe point us in two directions. First, the independence between public economic perceptions and the actual economic conditions may be due to a lack of knowledge in the early years of the transition. Second, we can expect postcommunist citizens to have adopted a more favorable interpretation of the reality due to more psychological mechanisms underlying opinion formation, such as relying on their predispositions to the new system, as well as having high hopes for the transition. In the prospective case, however, high hopes may have been grounded in quite rational calculations as people expected a newly emerging private sector to create more high-paying jobs and expand the consumer market (Aghion and Blanchard 1994; Rodrik 1995).

\section{The Formation of Economic Perceptions: Data and Measures}

Individual level data for my analysis come from the Central and Eastern Eurobarometer Study No. 3 conducted in October-November of 1992. The 1992 surveys were the last ones in the Central and Eastern Eurobarometer series that asked questions about sociotropic economic perceptions. The following studies only included questions about people's personal financial situation. However, 1992 is ideal as a starting point in modeling sociotropic economic perceptions in newly established democracies. We may expect that in 1992 memories of the old regime were still fresh, but also that after a few years of democratic reforms people had formed firm attitudes towards the new system. Thus, questions about sociotropic economic perceptions would most likely prompt people to make a comparison between the old and the new regimes. There are seventeen nations included in the surveys, for which I have complete data for both stages of the analysis: Albania, Armenia, Belarus, Bulgaria, the Czech Republic, Slovakia, Georgia, Hungary, Latvia, Lithuania, Macedonia, Moldova, Poland, Romania, Russia, Slovenia, and Ukraine.

Previous studies of economic voting have posed the question of whether voters are forward-looking or retrospective (MacKuen et al. 1992; Erikson et al. 2000; Suzuki and Cappell 1996; Suzuki 1991; Fiorina 1978). Although the rationality assumption prescribes voters to use prospective evaluations of the national economy, empirical analyses so far have shown more evidence supporting the reward-punishment hypothesis or retrospective voting across a wide range of 
countries (e.g. Fiorina 1981; Lewis-Beck 1988; see also Hesli and Bashkirova 2001). It is important to note, however, that it may be challenging to clearly separate retrospective from prospective voting. While voters appear retrospective, they may, in fact, use information about past economic performance to form economic forecasts. As collecting all relevant information to form accurate future predictions is costly, many voters may extrapolate from the past. After all, past is usually the best predictor of the future.

In post-communist countries, past studies of economic voting produced somewhat contradictory results with respect to the retrospective-prospective voting hypotheses (Pacek 1994; Przeworski 1996; Colton 1996; Harper 2000; Fidrmuc 2000a, b; see also Stokes 1996). In fact, some new democratic governments in those countries achieved reelection under economic conditions that would be considered fatal for any government in Western democracies. Given the mixed evidence of the importance between past and future economic assessments, I examine both retrospective and prospective sociotropic perceptions as my dependent variables. The retrospective variable is based on the survey question which asked respondents whether over the past twelve months the national economy in their countries has gotten much better, better, stayed the same, has gotten worse, or much worse. Similarly, the survey question about national economic forecasts asks for an evaluation of the economic situation one year from the date of the interview. The summary statistics on all the variables used in the study are available from the author upon request.

For macroeconomic indicators, I chose three economic indicators that have been most-widely used in the past studies of economic voting - the annual inflation, unemployment, and GDP growth rate as described in Table 1. Since the survey data were collected at the end of 1992 and given the wording of the dependent variable questions, I considered it most appropriate to employ the change measures of the inflation and growth rates from 1991 to 1992 (Anderson 1995). The underlying logic for using change measures is that people may react differently to the same level of unemployment and inflation in any given year depending on what the levels of unemployment and inflation had been in the previous year or even further back in history. For example, if the unemployment rate is running high in a certain year, but it is still a decrease compared to the recent history, people may perceive it as an improvement in the economic state. Theoretically, accounting for the recent economic history may be a better way to tap into public perceptions of the economy. Unfortunately, I am unable to use a change measure for unemployment rate due to the unavailability of the 1991 data for a number of nations. ${ }^{4}$ For detailed definitions and variable codes for all the variables in the model please contact the author directly.

\footnotetext{
4 Some may have a legitimate concern that coding unemployment as a level variable as opposed to a change variable may lead to a misspecification of the model. To insure my overall conclusions are not undermined by the choice of measurements, I ran the models with all the macroeconomic indicators measured at their 1992 levels. Neither system-level nor individual-level coefficients change to the extent that would lead me to reevaluate my theory. However, in case of inflation, the coefficient in the prospective case reaches statistical significance with the positive sign similar to unemployment. Substantively, though, the effect of inflation is still negligible.
} 


\section{Effects of Objective Economic Indicators on Sociotropic Perceptions}

The baseline multivariate models of economic perceptions (without taking account of the interactive effects) consist of the individual-level explanatory variables capturing people's personal economic situation, political preferences and evaluations, attitudes towards the reforms, political sophistication, and demographic characteristics, as well as the three measures of the objective economic state:

Retrospective perceptions $=f$ (objective economy, personal economic variables,

$$
\text { political attitudes, controls) }
$$

Prospective perceptions $=f$ (objective economy, retrospective sociotropic,

personal economic variables, political attitudes, controls)

Given the ordered nature of my dependent variables, I would have to use an estimation procedure designed to take it into consideration, such as ordered logit. However, methodologically, I have yet another potential problem to overcome. This problem is inherently imbedded in the very nature of the data that I am using. Specifically, my dependent variables and macroeconomic indicators are, in fact, measured at different levels. The unit of analysis of the sociotropic economic perceptions (the dependent variables) is an individual, whereas the unit of analysis of the objective economic indicators is a country. In case of multilevel or hierarchical data, traditional estimation methods, such as OLS, logit or ordered logit, do not produce the most efficient standard errors. In fact, they underestimate standard errors, which may lead to a higher risk of falsely rejecting the null hypothesis. Moreover, with the introduction of macro-level explanatory variables, it is no longer possible to use national dummy variables. Country dummies, which take care of a potential estimation bias due to omitted relevant effects measured at the level of a nation, produce perfect collinearity when used in the same model with substantive macro-level variables.

Estimation procedures for hierarchical models ${ }^{5}$ have become increasingly available to researchers either as specially designed statistical packages (e.g. MLwiN) or as a part of widely used statistical programs such as Stata. To increase the likelihood of obtaining unbiased and efficient estimates, I used the GLLAMM (Generalized Linear Latent and Mixed Models) estimation procedure with the ordered logit link function compatible with the Stata framework. In addition, I estimated the models with regular ordered logit for comparison purposes and as a reliability check to make sure the results were not just an artifact of the estimation method (ordered logit results are available from the author).

\footnotetext{
${ }^{5}$ A two-level hierarchical model can be given by the following notation: $y_{i j}=\beta_{0}+\sum_{q=1}^{Q} \beta_{0 q} z_{q j}+\sum_{p=1}^{P} \beta_{p 0} x_{r i j}+u_{0 j}+e_{i j}$, where $\beta_{0}$ is the intercept or constant, $\sum_{q=1}^{Q} \beta_{0 q} z_{q j}$ is a set of $\mathrm{Q}$ level-2 predictors $z_{\mathrm{qj}}(\mathrm{q}=1, \ldots, \mathrm{Q}), \sum_{p=1}^{P} \beta_{0 q} x_{p i j}$ is a set of $\mathrm{P}$ level-1 predictors $\mathrm{x}_{\mathrm{pij}}(\mathrm{p}=1, \ldots, \mathrm{P}), u_{0 j}$ is the residual level-2 variation in the level-1 intercept, and $e_{i j}$ is the disturbance capturing omitted level-1 predictors.
} 
Table 2 presents the results for the retrospective models analyzed by the hierarchical estimator. In the first column, the baseline model is estimated for the sample of survey respondents from all seventeen countries. Two of the macroeconomic estimates, inflation and growth, achieved the conventional levels of statistical significance, and the unemployment coefficient was not significant, although with the negative sign consistent with the reward-punishment hypothesis. The coefficients for inflation and GDP growth have the signs expected under the operation of the reward-punishment mechanism (Table 3).

Substantively, however, the positive effect of economic growth seems to be stronger than the negative effect of inflation. The total shift in the probability of forming favorable retrospective perceptions attributed to the growth variables is approximately $18.7 \%$ holding all the other variables at their means. In other words, moving up from the minimum to the maximum on the growth variable shifts the probability of having positive economic perceptions from 4 to $22.7 \%$. The total effect of inflation is substantively much smaller. ${ }^{6}$

In line with the second hypothesis, personal economic perceptions, evaluations of political reforms, feelings about the market as well as favorable sentiments toward the new regime correlate strongly with retrospective perceptions of the national economy. Perceived change in personal economic conditions is the strongest predictor of national economic evaluations. Specifically, the probability of having favorable retrospective perceptions increases from $4 \%$ among those who felt their own financial situation had gotten much worse to $49.5 \%$ among those who saw their financial situation having improved significantly. Also, individuals who liked the new political system better than the old one were $4 \%$ more likely to evaluate the national economy positively.

There seems to be only a weak mediating effect, however, of the system support variable on the relationship between objective economic indicators and retrospective sociotropic perceptions. This indicates that those who liked the new political system better than the old one did not seem to use economic information any differently than those more sympathetic to the old regime except in the case of inflation. The only significant interaction is between system support and inflation. Substantively, for instance, supporters of the new regime in the most economically successful country, Poland, were estimated to have a $21 \%$ probability of forming favorable perceptions of the economy, whereas Polish adherents of the old regime were only $15.3 \%$ likely to have optimistic assessments. In Ukraine, the least successful nation with regard to inflation, supporters of the reforms were $15.6 \%$ likely to have favorable perceptions, while supporters of the old regime had the probability of forming positive economic sentiments of $11 \%$. Given these results, it is reasonable to speculate that favorable feelings towards the new regime made people more tolerant of economic hardships.

The contingent effect of education on the relationship between objective economic indicators and retrospective perceptions is hardly noticeable. Although

\footnotetext{
6 The total effect of the inflation variable across its enormously wide range (minimum of $-260 \%$ to maximum of $2,570 \%$ ) constitutes a $-5.8 \%$ change in the probability of evaluating the past national economy positively. Put differently, the probability of having favorable retrospective perceptions decreases from 21.1 to $15.3 \%$ when moving from the lowest to the highest rate of inflation.
} 
Table 2 Determinants of sociotropic retrospective economic perceptions (Standard errors in parentheses)

\begin{tabular}{|c|c|c|c|c|}
\hline \multirow[t]{2}{*}{ Independent variable } & \multicolumn{4}{|c|}{ Retrospective } \\
\hline & $\begin{array}{l}\text { Base } \\
\text { model }\end{array}$ & $\begin{array}{l}\text { System } \\
\text { interact }\end{array}$ & $\begin{array}{l}\text { Educ } \\
\text { interact }\end{array}$ & $\begin{array}{l}\text { Pol disc } \\
\text { interact }\end{array}$ \\
\hline Inflation rate (change) & $\begin{array}{l}-0002^{*} \\
(.0001)\end{array}$ & $\begin{array}{l}-.0002 \\
(.0001)\end{array}$ & $\begin{array}{l}-.0001 \\
(.0001)\end{array}$ & $\begin{array}{l}-.0002 * \\
(.0001)\end{array}$ \\
\hline Unemployment rate & $\begin{array}{l}-.019 \\
(.013)\end{array}$ & $\begin{array}{l}-.024 \\
(.013)\end{array}$ & $\begin{array}{l}-.029 * * \\
(.011)\end{array}$ & $\begin{array}{l}-.023^{*} \\
(.011)\end{array}$ \\
\hline Growth rate (change) & $\begin{array}{l}.031 * * * \\
(.006)\end{array}$ & $\begin{array}{l}.030 * * * \\
(.007)\end{array}$ & $\begin{array}{l}.031 * * * \\
(.007)\end{array}$ & $\begin{array}{l}.028 * * * \\
(.007)\end{array}$ \\
\hline Egocentric retrospective economic evaluations & $\begin{array}{l}.769 * * * \\
(.020)\end{array}$ & $\begin{array}{l}.769 * * * \\
(.020)\end{array}$ & $\begin{array}{l}.771 * * * \\
(.020)\end{array}$ & $\begin{array}{l}.768 * * * \\
(.020)\end{array}$ \\
\hline Income & $\begin{array}{l}-.013 * \\
(.006)\end{array}$ & $\begin{array}{l}-.014 * \\
(.006)\end{array}$ & $\begin{array}{l}-.015^{*} \\
(.006)\end{array}$ & $\begin{array}{l}-.013 * \\
(.006)\end{array}$ \\
\hline Unemployment status & $\begin{array}{l}.070 \\
(.074)\end{array}$ & $\begin{array}{l}.067 \\
(.074)\end{array}$ & $\begin{array}{l}.070 \\
(.074)\end{array}$ & $\begin{array}{l}.074 \\
(.074)\end{array}$ \\
\hline Satisfaction with democracy & $\begin{array}{l}.466 * * * \\
(.027)\end{array}$ & $\begin{array}{l}.462 * * * \\
(.027)\end{array}$ & $\begin{array}{l}.467 * * * \\
(.027)\end{array}$ & $\begin{array}{l}.465 * * * \\
(.027)\end{array}$ \\
\hline Like new political system & $\begin{array}{l}.349 * * * \\
(.060)\end{array}$ & & & \\
\hline Like old political system & $\begin{array}{l}-.038 \\
(.059)\end{array}$ & & & \\
\hline Like new/old system dummy & & $\begin{array}{l}.444 * * * \\
(.090)\end{array}$ & $\begin{array}{l}.372 * * * \\
(.044)\end{array}$ & $\begin{array}{l}.379 * * * \\
(.044)\end{array}$ \\
\hline Attitudes toward market & $\begin{array}{l}.198 * * * \\
(.043)\end{array}$ & $\begin{array}{l}.205 * * * \\
(.043)\end{array}$ & $\begin{array}{l}.206 * * * \\
(.043)\end{array}$ & $\begin{array}{l}.203^{* * *} \\
(.043)\end{array}$ \\
\hline Attitudes toward the speed of the reforms & $\begin{array}{l}.494 * * * \\
(.050)\end{array}$ & $\begin{array}{l}.493 * * * \\
(.050)\end{array}$ & $\begin{array}{l}.490 * * * \\
(.050)\end{array}$ & $\begin{array}{l}.492 * * * \\
(.050)\end{array}$ \\
\hline Education/education dummy & $\begin{array}{l}-.022 \\
(.021)\end{array}$ & $\begin{array}{l}-.024 \\
(.021)\end{array}$ & $\begin{array}{l}-.061 \\
(.084)\end{array}$ & $\begin{array}{l}-.023 \\
(.021)\end{array}$ \\
\hline Political discussion/polit disc dummy & $\begin{array}{l}-.124 * * * \\
(.029)\end{array}$ & $\begin{array}{l}-.126^{* * *} \\
(.029)\end{array}$ & $\begin{array}{l}-.126^{* * *} \\
(.029)\end{array}$ & $\begin{array}{l}-.282 * * \\
(.085)\end{array}$ \\
\hline Gender & $\begin{array}{l}.057 \\
(.037)\end{array}$ & $\begin{array}{l}.056 \\
(.037)\end{array}$ & $\begin{array}{l}.057 \\
(.037)\end{array}$ & $\begin{array}{l}.058 \\
(.037)\end{array}$ \\
\hline Age & $\begin{array}{l}-.004 * * * \\
(.001)\end{array}$ & $\begin{array}{l}-.005^{* * *} \\
(.001)\end{array}$ & $\begin{array}{l}-.005^{* * *} \\
(.001)\end{array}$ & $\begin{array}{l}-.004^{* *} \\
(.001)\end{array}$ \\
\hline \multicolumn{5}{|l|}{ Political system } \\
\hline Inflation* & & $\begin{array}{l}-.0001 * * \\
(.0001)\end{array}$ & & \\
\hline Unemployment* & & $\begin{array}{l}.005 \\
(.007)\end{array}$ & & \\
\hline
\end{tabular}


Table 2 continued

\begin{tabular}{|c|c|c|c|c|}
\hline \multirow[t]{2}{*}{ Independent variable } & \multicolumn{4}{|c|}{ Retrospective } \\
\hline & $\begin{array}{l}\text { Base } \\
\text { model }\end{array}$ & $\begin{array}{l}\text { System } \\
\text { interact }\end{array}$ & $\begin{array}{l}\text { Educ } \\
\text { interact }\end{array}$ & $\begin{array}{l}\text { Pol disc } \\
\text { interact }\end{array}$ \\
\hline Growth* & & $\begin{array}{l}.002 \\
(.003)\end{array}$ & & \\
\hline \multicolumn{5}{|l|}{ Polit Sophistication } \\
\hline Inflation* & & & $\begin{array}{l}-.0002 * * \\
(.0001)\end{array}$ & $\begin{array}{l}.00002 \\
(.0001)\end{array}$ \\
\hline Unemployment* & & & $\begin{array}{l}.014 * \\
(.006)\end{array}$ & $\begin{array}{l}.009 \\
(.006)\end{array}$ \\
\hline Growth* & & & $\begin{array}{l}.0002 \\
(.004)\end{array}$ & $\begin{array}{l}.006 \\
(.003)\end{array}$ \\
\hline Country-level variance & $\begin{array}{l}.125 \\
(.030)\end{array}$ & $\begin{array}{l}.136 \\
(.031)\end{array}$ & $\begin{array}{l}.140 \\
(.032)\end{array}$ & $\begin{array}{l}.149 \\
(.033)\end{array}$ \\
\hline$N$ & 11118 & 11118 & 11118 & 11118 \\
\hline
\end{tabular}

$* P<.05 * * P<.01 * * * P<.001$ (two-tailed)

statistically significant, the difference in the probability of forming unfavorable economic perceptions as a function of growing inflation varies by less than $1.5 \%$ between the two educational groups. The negative effect of unemployment is even more negligible.

Finally, frequent political discussions did not generate more awareness of the national economic conditions or at least higher reliance on objective information when forming sociotropic assessments of the economy. Worth noting, however, is the independent negative effect of political discussion on past economic perceptions, which is both statistically and substantively significant. The finding echoes previous works on political discourse in post-communist societies, which documented its negative nature.

The impact of objective economic conditions on perceived future economy is quite minimal. Statistically, the only significant relationship is between the rate of unemployment and people's economic forecasts, but the direction is positive, and thus contrary to the reward-punishment thesis. This result, however, is consistent with alternative government support models previously found in transitional societies. Since system transitions do not happen overnight and are expected to create better economic opportunities, people may stay optimistic about the future when the current economic conditions are deteriorating. They may, in fact, interpret it as a sign of working reforms. Subjective evaluations of personal economy, retrospective sociotropic perceptions, as well as satisfaction with political and economic reforms also associate with national economic forecasts. However, we should be cautious with identifying the direction of these relationships. As with almost any cross-national survey study, there is a concern with some variables being endogenous to the model. Thus, theoretically, it is possible to assume that whereas 
Table 3 Determinants of sociotropic prospective economic perceptions (Standard errors in parentheses)

\begin{tabular}{|c|c|c|c|c|}
\hline \multirow[t]{2}{*}{ Independent variable } & \multicolumn{4}{|c|}{ Prospective } \\
\hline & $\begin{array}{l}\text { Base } \\
\text { model }\end{array}$ & $\begin{array}{l}\text { System } \\
\text { interact }\end{array}$ & $\begin{array}{l}\text { Educ } \\
\text { interact }\end{array}$ & $\begin{array}{l}\text { Pol disc } \\
\text { interact }\end{array}$ \\
\hline Inflation rate (change) & $\begin{array}{l}.0001 \\
(.0001)\end{array}$ & $\begin{array}{l}.0001 \\
(.0001)\end{array}$ & $\begin{array}{l}.00002 \\
(.0001)\end{array}$ & $\begin{array}{l}.0001 \\
(.0001)\end{array}$ \\
\hline Unemployment rate & $\begin{array}{l}.023^{*} \\
(.010)\end{array}$ & $\begin{array}{l}.024 * \\
(.010)\end{array}$ & $\begin{array}{l}.024 * \\
(.010)\end{array}$ & $\begin{array}{l}.023^{*} \\
(.010)\end{array}$ \\
\hline Growth rate (change) & $\begin{array}{l}.002 \\
(.004)\end{array}$ & $\begin{array}{l}.003^{*} \\
(.004)\end{array}$ & $\begin{array}{l}-.002 \\
(.005)\end{array}$ & $\begin{array}{l}.005 \\
(.004)\end{array}$ \\
\hline Sociotropic retrospective economic evaluations & $\begin{array}{l}.480 * * * \\
(.022)\end{array}$ & $\begin{array}{l}.492 * * * \\
(.022)\end{array}$ & $\begin{array}{l}.480 * * * \\
(.022)\end{array}$ & $\begin{array}{l}.481 * * * \\
(.022)\end{array}$ \\
\hline Egocentric retrospective economic evaluations & $\begin{array}{l}.104 * * * \\
(.022)\end{array}$ & $\begin{array}{l}.105^{* * *} \\
(.022)\end{array}$ & $\begin{array}{l}.105^{* * *} \\
(.022)\end{array}$ & $\begin{array}{l}.104 * * * \\
(.022)\end{array}$ \\
\hline Egocentric prospective economic evaluations & $\begin{array}{l}.948 * * * \\
(.023)\end{array}$ & $\begin{array}{l}.948 * * * \\
(.023)\end{array}$ & $\begin{array}{l}.947 * * * \\
(.023)\end{array}$ & $\begin{array}{l}.948 * * * \\
(.023)\end{array}$ \\
\hline Income & $\begin{array}{l}-.016^{*} \\
(.007)\end{array}$ & $\begin{array}{l}-.017 * \\
(.007)\end{array}$ & $\begin{array}{l}-.017 * \\
(.007)\end{array}$ & $\begin{array}{l}-.016^{*} \\
(.007)\end{array}$ \\
\hline Unemployment status & $\begin{array}{l}-.034 \\
(.079)\end{array}$ & $\begin{array}{l}-.035 \\
(.079)\end{array}$ & $\begin{array}{l}-.037 \\
(.079)\end{array}$ & $\begin{array}{l}-.035 \\
(.079)\end{array}$ \\
\hline Satisfaction with democracy & $\begin{array}{l}.356^{* * *} \\
(.028)\end{array}$ & $\begin{array}{l}.356 * * * \\
(.028)\end{array}$ & $\begin{array}{l}.355^{* * * *} \\
(.028)\end{array}$ & $\begin{array}{l}.355 * * * \\
(.028)\end{array}$ \\
\hline Like new political system & $\begin{array}{l}.260 * * * \\
(.064)\end{array}$ & & & \\
\hline Like old political system & $\begin{array}{l}.037 \\
(.062)\end{array}$ & & & \\
\hline Like new/old system dummy & & $\begin{array}{l}.168 \\
(.093)\end{array}$ & $\begin{array}{l}.235 * * * \\
(.046)\end{array}$ & $\begin{array}{l}.231 * * * \\
(.046)\end{array}$ \\
\hline Attitudes toward market & $\begin{array}{l}.227 * * * \\
(.045)\end{array}$ & $\begin{array}{l}.222 * * * \\
(.047)\end{array}$ & $\begin{array}{l}.229 * * * \\
(.045)\end{array}$ & $\begin{array}{l}.223 * * * \\
(.047)\end{array}$ \\
\hline Attitudes toward the speed of the reforms & $\begin{array}{l}.125^{*} \\
(.055)\end{array}$ & $\begin{array}{l}.128 * \\
(.055)\end{array}$ & $\begin{array}{l}.123^{*} \\
(.055)\end{array}$ & $\begin{array}{l}.127 * \\
(.055)\end{array}$ \\
\hline Education & $\begin{array}{l}.009 \\
(.022)\end{array}$ & $\begin{array}{l}.009 \\
(.028)\end{array}$ & $\begin{array}{l}-.072 \\
(.088)\end{array}$ & $\begin{array}{l}.008 \\
(.022)\end{array}$ \\
\hline Political discussion & $\begin{array}{l}-.019 \\
(.031)\end{array}$ & $\begin{array}{l}-.017 \\
(.031)\end{array}$ & $\begin{array}{l}-.015 \\
(.031)\end{array}$ & $\begin{array}{l}.020 \\
(.089)\end{array}$ \\
\hline Gender & $\begin{array}{l}.174 * * * \\
(.039)\end{array}$ & $\begin{array}{l}.175 * * * \\
(.039)\end{array}$ & $\begin{array}{l}.176^{* * * *} \\
(.039)\end{array}$ & $\begin{array}{l}.173 * * * \\
(.039)\end{array}$ \\
\hline Age & $\begin{array}{l}.005^{* * *} \\
(.001)\end{array}$ & $\begin{array}{l}.005^{* * *} \\
(.001)\end{array}$ & $\begin{array}{l}.004 * * \\
(.001)\end{array}$ & $\begin{array}{l}.005 * * * \\
(.001)\end{array}$ \\
\hline Political System & & & & \\
\hline Inflation* & & $\begin{array}{l}.0001 \\
(.0001)\end{array}$ & & \\
\hline
\end{tabular}


Table 3 continued

\begin{tabular}{|c|c|c|c|c|}
\hline \multirow[t]{2}{*}{ Independent variable } & \multicolumn{4}{|c|}{ Prospective } \\
\hline & $\begin{array}{l}\text { Base } \\
\text { model }\end{array}$ & $\begin{array}{l}\text { System } \\
\text { interact }\end{array}$ & $\begin{array}{l}\text { Educ } \\
\text { interact }\end{array}$ & $\begin{array}{l}\text { Pol disc } \\
\text { interact }\end{array}$ \\
\hline \multirow[t]{2}{*}{ Unemployment* } & & .002 & & \\
\hline & & $(.007)$ & & \\
\hline \multirow[t]{2}{*}{ Growth* } & & -.003 & & \\
\hline & & $(.004)$ & & \\
\hline \multicolumn{5}{|l|}{ Polit Sophistication } \\
\hline \multirow[t]{2}{*}{ Inflation* } & & & .0001 & -.0001 \\
\hline & & & $(.0001)$ & $(.0001)$ \\
\hline \multirow[t]{2}{*}{ Unemployment* } & & & .001 & -.001 \\
\hline & & & $(.007)$ & $(.007)$ \\
\hline \multirow[t]{2}{*}{ Growth* } & & & .004 & -.007 \\
\hline & & & $(.004)$ & $(.003)$ \\
\hline \multirow[t]{2}{*}{ Country-level variance } & .081 & .087 & .089 & .084 \\
\hline & $(.022)$ & $(.024)$ & $(.024)$ & $(.023)$ \\
\hline$N$ & 9767 & 9767 & 9767 & 9767 \\
\hline
\end{tabular}

$* P<.05 * * P<.01 * * * P<.001$ (two-tailed)

retrospective perceptions may determine economic forecasts, people's optimism about the future projected back to retrospective economic evaluations. The interaction variables with system support, education and political discussion in any of the models failed to achieve conventional levels of statistical significance. Those who held favorable attitudes toward the new political system and transition reforms were, on average, more likely to believe in the brighter economic future. Those who felt more pessimistic about the politico-economic transformation were also more skeptical about the prospects of the national economy regardless of the objective economic state.

Overall, the results of both retrospective and prospective models indicate a substantively weak correlation between public perceptions and economic reality. Whether a function of limited economic knowledge or high hopes for the future, popular perceptions of the economy in the wake of post-communist transition could hardly be considered a referendum on past economic performance. Instead they looked more like a referendum on the newly established democratic system and a reflection of people's personal economic well-being. Notably, the degree of economic accuracy was little affected by individuals' cognitive resources.

\section{Discussion and Conclusions}

The current economic crisis brought the issue of public economic perceptions to the forefront of heated political discussions. While experts make predictions about the 
path and the speed of economic recovery and argue about the effectiveness of past and current solutions, citizens, overwhelmed by the complexity of the discussion, form their own judgments about the economy. According to one of the latest CNN public opinion polls (October 5-7, 2010), only 17\% of Americans believe that the economy has started to recover, $44 \%$ think that it is stable, but not recovered, and $38 \%$ still feel the economy is in downturn. ${ }^{7}$ What could possibly explain this variation in people's sociotropic views when the media continuously reports on main economic indicators? One explanation is that individuals have differing personal economic experiences and extrapolate from them. However, most people understand that their personal economic fortunes or misfortunes do not directly translate to the macroeconomic situation. Yet they do not live in a vacuum. Through the media and private discussions the public learns about the economic fate of their fellow citizens. Adding this information to their own experiences gives people a general idea of the national economy.

This is not the only explanation, however. Numerous studies of public opinion and economic voting found that individuals tend to filter economic (and other) information based on their political predispositions. The same CNN poll shows that among Republican voters only $8 \%$ have a positive outlook on the economy, while among Democrats $27 \%$ believe that the economic situation has been showing signs of recovery. Negative views of the economy reveal even a starker contrast between Democratic and Republican supporters. Whereas only $17 \%$ of the former think that the economy is still in downturn, it is $47 \%$ of the latter who believe it is true. It is noteworthy that these variations in sociotropic evaluations are not nearly as pronounced across different age groups, educational levels or income levels.

When I started the current project, the major puzzle I saw was the level of economic optimism in the wake of post-communist transition. How could anyone at the end of 1992 — one of the worst years in the economic history of that region-still believe that the economy had been improving or have such high hopes for the future? Voluminous theoretical and empirical studies on how people form judgments in developed democracies led me to believe that similar mechanisms (but with certain variations) should be at work in emerging democracies. When information is scarce or complex, individuals have a tendency to rely on heuristics and shortcuts of which the most powerful is their own personal experience. As expected, during the early post-communist transition, individuals who felt their personal economic situation was improving had a more optimistic outlook on the national economy.

In addition, people look at the economy through the prism of their political beliefs. With the collapse of the communist system and even before it, many citizens in East Central Europe became disillusioned with the communist ideology and the Communist Party. New political parties mushroomed in dozens bringing about new ideological views, often radical or obscure. Lost in this sea of information, the majority of post-communist citizens were cautious to form strong allegiances to new political parties. Most, however, were able to express their views

\footnotetext{
7 The full results of the CNN poll can be found here: http://i2.cdn.turner.com/cnn/2010/images/ 10/08/rel14a.pdf.
} 
about the new and old political order. These general attitudes towards the regime transition served as heuristics for processing complex economic information. Those who supported the new system were likely to form more positive retrospective and prospective perceptions of the economy, whereas those opposed to it were more likely to express negative views. In light of a high likelihood of endogeneity between variables measuring political attitudes and economic perceptions, I exercise caution while interpreting the magnitude of these effects.

Overall, the findings of this study demonstrate that in the face of uncertainty, whether it is related to the past or future, people still make judgments on various issues. In the countries of East Central Europe at the beginning of the postcommunist transition, uncertainty about new political and economic systems was especially high due to the volatile economy, radical institutional changes, and insufficient public knowledge about the systems. Low or unintuitive (with the "wrong" sign) correlation between objective economic indicators and individual economic perceptions, according to some scholars of transition, does not necessarily presume irrationality. Instead, post-communist citizens may have very well understood that the radical systemic transformation could not happen overnight and demonstrated a certain degree of patience in their economic assessments. Moreover, others believe that state workers may have taken the deteriorating economy as a sign that the reforms were going in the right direction. Market reforms are expected to create more high-paying jobs in the private sector and improve workers' conditions in the long run. In fact, my results indicate that those approving of the speed of the reforms were more likely to develop positive sentiments of the economy (both retrospective and prospective).

Consequently, if we believe that economic voting existed during the early transformation phase, as claimed by a number of studies (Pacek 1994; Przeworski 1996; Colton 1996; Harper 2000; Fidrmuc 2000a, b; Tucker 2002, 2006), it is doubtful that post-communist citizens cast referendum votes based on the national economic performance. Instead, it is likely that their voting behavior was motivated by economic expectations or driven by personal experiences, political attitudes and assessments of the transition reforms.

These arguments can certainly be generalized beyond the scope of the postcommunist transition in East Central Europe. Any country that undergoes an economic and/or political transition, or experiences some sort of turmoil, may reveal a greater disjuncture between public economic perceptions and economic reality. This growing independence of economic assessments from the reality could be either a sign of people's inability to make accurate evaluations or, alternatively, a shift in their judgments of the reality. A lack of congruence between objective and subjective economies, in turn, may lead to a breach in the accountability mechanism, which in new democracies may consequently result in authoritarian backsliding.

Acknowledgments I am deeply grateful to Christopher Anderson, Michael McDonald, David Rueda, and Russell Dalton for their invaluable feedback on the earlier drafts of the manuscript. I would also like to thank Ryan Shirah for his research assistance, and the anonymous referees for their constructive criticism and helpful suggestions. 
Open Access This article is distributed under the terms of the Creative Commons Attribution Noncommercial License which permits any noncommercial use, distribution, and reproduction in any medium, provided the original author(s) and source are credited.

\section{References}

Aghion, P., \& Blanchard, O. J. (1994). On the speed of transition in Central Europe. NBER Macro Annuals, 9, 283-320.

Ahl, R. (1999). Society and transition in Post-Soviet Russia. Communist and Post-Communist Studies, 32 , $175-193$.

Alvarez, M. R., \& Nagler, J. (1998). Economics, entitlements, and social issues: voter choice in the 1996 presidential election. American Journal of Political Science, 42, 1349-1363.

Anderson, C. J. (1995). Blaming the Government: citizens and the economy in five European Democracies. Armonk: M. E. Sharpe.

Anderson, C. J. (2007). The end of economic voting? contingency dilemmas and the limits of democratic accountability. Annual Review of Political Science, 10, 271-296.

Anderson, C. J., Blais, A., Bowler, S., Donovan, T., \& Listhaug, O. (2007). Losers' consent: Elections and democratic legitimacy. New York: Oxford University Press.

Anderson, C. J., Mendes, S., \& Tverdova, Y. V. (2004). Endogenous economic perceptions: Evidence from the 1997 British election. Electoral Studies, 23, 683-708.

Anderson, C. J., \& O'Connor, K. M. (2000). System change, learning and public opinion about the economy. British Journal of Political Science, 29, 215-240.

Babad, E. (1987). Wishful thinking and objectivity among sports fans. Social Behavior, 2, 231-240.

Babad, Elisha. (1995). Can accurate knowledge reduce wishful thinking in voters' predictions of election outcomes? Journal of Psychology, 129, 285-300.

Babad, E., Hills, M., \& O'Driscoll, M. (1992). Factors influencing wishful thinking and predictions of election outcomes. Basic and Applied Social Psychology, 13, 461-476.

Babad, E., \& Katz, Y. (1991). Against All Odds. Journal of Applied Social Psychology, 21, 1921-1938.

Babad, E., \& Yacobos, E. (1993). Wish and reality in voter's predictions of election outcomes. Political Psychology, 14, 37-54.

Baum, M. A. (2002). The constituent foundations of the rally-round-the-flag phenomenon. International Studies Quarterly, 46, 263-298.

Berggren, H. M. (2001). Institutional context and reduction of the resource bias in political sophistication. Political Research Quarterly, 54, 531-552.

Borre, O. (1997). Economic voting in Danish Electoral Surveys 1987-1994. Scandinavian Political Studies, 20, 347-365.

Colton, T. J. (1996). Economics and voting in Russia. Post-Soviet Affairs, 12, 289-317.

Colton, T. J. (2000). Transitional citizens: voters and what influences them in the New Russia. Cambridge: Harvard University Press.

Conover, P. J., Feldman, S., \& Knight, K. (1986). Judging inflation and unemployment: the origins of retrospective evaluations. Journal of Politics, 48, 565-588.

Conover, P. J., Feldman, S., \& Knight, K. (1987). The personal and political underpinnings of economic forecasts. American Journal of Political Science, 31, 559-583.

Dolan, K. A., \& Holbrook, T. M. (2001). Knowing versus caring: the role of affect and cognition in political perceptions. Political Psychology, 22, 27-44.

Duch, R. M. (1993). Tolerating economic reform: popular support for transition to a free market in the former Soviet Union. American Political Science Review, 87, 590-608.

Duch, H. M., Palmer, H. D., \& Anderson, C. J. (2000). Heterogeneity in perceptions of national economic conditions. American Journal of Political Science, 44, 635-653.

Enns, P. K., \& Anderson, C. J. (2009). The American voter goes shopping: micro-foundations of the partisan economy. Paper presented at the annual meeting of the American Political Science Association, Toronto.

Enns, P. K., Kellstedt, P. M., \& McAvoy, G. E. (2008). The consequences of partisanship in economic perceptions. Paper presented at the Annual Meeting of the American Political Science Association, Boston. 
Erikson, R. S., MacKuen, M. B., \& Stimson, J. A. (2000). Bankers or peasants revisited: economic expectations and presidential approval. Electoral Studies, 19, 295-312.

Evans, G. (1999). Economics and politics revisited: exploring the decline in conservative support, 1992-95. Political Studies, 47, 139-151.

Evans, G., \& Andersen, R. (2006). The political conditioning of economic perceptions. Journal of Politics, 68, 194-207.

Festinger, L. (1957). A Theory of Cognitive Dissonance. Stanford: Stanford University Press.

Fidrmuc, J. (2000a). Economics of voting in post-communist countries. Electoral Studies, 19, 199-217.

Fidrmuc, J. (2000b). Political support for reforms: economic of voting in transition countries. European Economic Review, 44, 1491-1513.

Fiorina, M. P. (1978). Economic retrospective voting in American National Elections: a micro-analysis. American Journal of Political Science, 22, 426-443.

Fiorina, M. P. (1981). Retrospective voting in American National elections. New Haven: Yale University Press.

Gerber, A. S., \& Huber, G. A. (2009). Partisanship and economic behavior: do partisan differences in economic forecasts predict real economic behavior? American Political Science Review, 103, $407-426$.

Gerber, A. S., \& Huber, G. A. (2010). Partisanship, political control, and economic assessments. American Journal of Political Science, 54, 153-173.

Gibson, J. L. (1996a). A mile wide but an inch deep(?): the structure of democratic commitments in the former USSR. American Journal of Political Science, 40, 396-420.

Gibson, J. L. (1996b). Political and economic markets: changes in the connection between attitudes toward political democracy and the market economy within the mass culture of Russia and Ukraine. Journal of Politics, 58, 954-984.

Gilovich, T., Griffin, D., \& Kahneman, D. (2002). Heuristics and biases: the psychology of intuitive judgment. New York: Cambridge University Press.

Goren, P. (2004). Political sophistication and policy reasoning: a reconsideration. American Journal of Political Science, 48, 462-478.

Granberg, D., \& Brent, E. (1983). When prophecy bends: the preference-expectation link in u.s. presidential elections, 1952-1980. Journal of Personality and Social Psychology, 45, 477-491.

Harper, M. (2000). Economic voting in Post-Communist Eastern Europe. Comparative Political Studies, 33, 1191-1227.

Hesli, V. L., \& Bashkirova, E. (2001). The impact of time and economic circumstances on popular evaluations of Russia's President. International Political Science Review, 22, 379-398.

Jensen, N. M. (2003). Rational citizens against reform: poverty and economic reform in transition economies. Comparative Political Studies, 36, 1092-1111.

Johnston, R., Sparker, R., Kelvyn, J., Bolster, A., Propper, C., \& Burgess, S. (2005). Egocentric economic voting and changes in party choice: Great Britain 1992-2001. Journal of Elections, Public Opinion and Parties, 15, 129-144.

Kahneman, D., Paul, S., \& Tversky, A. (Eds.). (1982). Judgment under uncertainty: heuristics and biases. New York: Cambridge University Press.

Karp, J. A., Banducci, S. A., \& Bowler, S. (2003). To know it is to love it? Satisfaction with democracy in the European Union. Comparative Political Studies, 36, 271-292.

Kuklinski, J. H., Quirk, P. J., Jerit, J., \& Rich, R. F. (2001). The political environment and citizen competence. American Journal of Political Science, 45, 410-424.

Kumlin, S. (2001). Ideology-driven opinion formation in Europe: the case of attitudes towards the third sector in Sweden. European Journal of Political Research, 39, 487-518.

Kunda, Z. (1990). The case for motivated reasoning. Psychological Bulletin, 108, 480-498.

Ladner, M., \& Wlezien, C. (2007). Partisan preferences, electoral prospects, and economic expectations. Comparative Political Studies, 40, 571-596.

Lau, R. R., \& Redlawsk, D. P. (2001). Advantages and disadvantages of cognitive heuristics in political decision making. American Journal of Political Science, 45, 951-971.

Lavine, H., Lodge, M., \& Freitas, K. (2005). Threat, authoritarianism, and selective exposure to information. Political Psychology, 26, 219-244.

Lewis-Beck, Michael. S. (1988). Economics and elections: the major western democracies. Ann Arbor: University of Michigan Press.

Lewis-Beck, M. S., Nadeau, R., \& Elias, A. (2008). Economics, party, and the vote: causality issues and panel data. American Journal of Political Science, 52, 84-95. 
MacKuen, M. B., Erikson, R. S., \& Stimson, J. S. (1992). Peasant or Bankers?. The American Electorate and the US Economy. American Political Science Review, 86, 597-611.

Mattila, A. (1998). An examination of consumers' use of heuristic cues in making satisfaction judgments. Psychology and Marketing, 15, 477-501.

Mutz, D. C. (1992). Mass media and the depoliticization of personal experience. American Journal of Political Science, 36, 483-508.

Nannestad, P., \& Paldam, M. (2000). Into Pandora's Box of economic evaluations: a study of the Danish Macro VP-function. 1986-1997. Electoral Studies, 19, 123-140.

Nannestad, P., Paldam, M., \& Rosholm, M. (2003). System change and economic evaluations: a study of immigrants and natives in Israel. Electoral Studies, 22, 485-501.

Neuwirth, K., Frederick, E., \& Mayo, C. (2002). Person-effects and heuristics-systematic processing. Communication Research, 29, 320-359.

Pacek, A. C. (1994). Macroeconomic conditions and electoral politics in East Central Europe. American Journal of Political Science, 38, 723-744.

Page, B. I., \& Shapiro, R. Y. (1992). The rational public: fifty years of trends in Americans' policy preferences. Chicago: University of Chicago Press.

Plous, S. (1993). The psychology of judgment and decision making. New York: McGraw-Hill.

Przeworski, A. (1991). Democracy and the market: political and economic reforms in Eastern Europe and Latin America. New York: Cambridge University Press.

Przeworski, A. (1996). Public support for economic reform in Poland. Comparative Political Studies, 29, $520-543$.

Ries, N. (1997). Russian talk: culture and conversation during Perestroika. Ithaca: Cornell University Press.

Rodrik, D. (1995). The dynamics of political support for reform in economies in transition. Journal of the Japanese and International Economies, 9, 403-425.

Shevchenko, O. (2001). Bread and circuses: shifting frames and changing references in ordinary muscovites' political talk. Communist and Post-Communist Studies, 34, 77-90.

Stokes, S. (1996). Introduction. Public opinion and market reforms: the limits of economic voting. Comparative Political Studies, 29, 499-519.

Stokes, S. (2001). Introduction: public opinion of market reforms: a framework. In S. C. Stokes (Ed.), Public support for market reforms in new democracies (pp. 1-32). New York: Cambridge University Press.

Suzuki, M. (1991). The rationality of economic voting and the macroeconomic regime. American Journal of Political Science, 35, 624-642.

Suzuki, M., \& Cappell, H. W. (1996). The rationality of economic voting revisited. Journal of Politics, $58,224-236$.

Tóka, G. (1995). Being represented: being satisfied? Political support in East Central Europe. In H.-D. Klingemann \& D. Fuchs (Eds.), Citizens and the State (pp. 354-382). Oxford: Oxford University Press.

Tucker, J. A. (2002). The first decade of post-communist elections and voting: What have we studies, and how have we studied it? Annual Review of Political Science, 5, 271-304.

Tucker, J. A. (2006). Regional economic voting: Russia, Poland, Hungary, Slovakia, and the Czech Republic, 1990-1999. New York: Cambridge University Press.

Vláchová, K. (2001). Party identification in the Czech Republic: inter-party hostility and party preference. Communist and Post-Communist Studies, 34, 479-499.

Wlezien, C., Franklin, M., \& Twiggs, D. (1997). Economic perceptions and the vote choice: disentangling the endogeneity. Political Behavior, 19, 7-17.

Zaller, J. R. (1992). The nature and origins of mass opinion. New York: Cambridge University Press. 